\title{
Labour law, enforcement and the rise of temporary contract workers: empirical evidence from India's organised manufacturing sector
}

\author{
Rahul Suresh Sapkal ${ }^{1}$
}

Published online: 14 September 2015

(C) The Author(s) 2015. This article is published with open access at Springerlink.com

\begin{abstract}
There is an intense debate on the impact of labour regulation in India today. Labour regulation in India differ state-wise and apply differently across types of workers (both regular and contract workers). This paper examines the joint effects of Employment Protection Legislation (EPL) and variable enforcement intensity on the growth in a size of temporary contract workers in the organised manufacturing sector. It uses the state level amendments to Industrial Dispute Act of 1947 , and the average size of total number of labour inspectors for each state, as independent variables to capture the variation in labour regulations and enforcement intensity across thirty-one Indian states for the period 2000-2007. This paper argues that, average Indian firms located in strict EPL states hire differentially more temporary contract workers as compare to regular workers in response to variable enforcement intensity. Among other findings, the empirical analysis shows that firms prefer to employ excessive number of contract workers to circumvent firing and overall compliance costs of regular workers as stipulated by the Indian labour laws. Our results are robust to alternative specifications.
\end{abstract}

Keywords India $\cdot$ Contract workers $\cdot$ Labour regulation $\cdot$ Enforcement

JEL Classification $\mathrm{J} 16 \cdot \mathrm{K} 21 \cdot \mathrm{K} 31$

Rahul Suresh Sapkal

rahul.sapkal@edle-phd.eu

1 European Doctorate Programe in Law and Economics and Institute of Law and Economics, Universität Hamburg, Hamburg, Germany 


\section{Introduction}

The effect of Employment Protection Legislation (EPL) on the growth in a size of temporary contract workers in developing countries is widely debated in the recent economic literature. Since the past two decades, the share of temporary contract workers as compared to regular workers has increased rapidly (ILO 2012). A segment of temporary contract workers mainly consists of those who are recruited by firms through third party contractors or temporary work agencies, and who lack the security of a definite tenure as well as basic employment protection. Temporary contract workers not only constitute a significant share of the labour market in developing countries, but their share has also seen a substantial rise in many developed countries. ${ }^{1}$ At a micro level, this growth has closely been associated with an attempt to increase labour market flexibility-an employment adjustment technique for flexible management of labour (OECD 2014). In the absence of this flexibility, labour markets in many developing economies would likely to experience high levels of unemployment. Firms in developing countries tend to depend excessively on temporary contract workers as it enables them to adapt to fluctuations in the business cycles. Thus, this growth has generally been perceived as a positive development in the labour market. On the other hand, this positive development has its own drawback. A growth in their share is coupled with poor working condition, low productivity and lack of social cohesion with regular workers (World Bank 2012). This suggests that the demand for temporary contract workers to adjust firms' workforce is actually making them more vulnerable workforce, if they are not covered under any employment protection laws. And therefore, it is likely that supply and demand factors could have influenced the growth of temporary contract workers.

Earlier studies argues that the growth in a size of temporary contract workers is triggered by the stringent EPL, in particular strict dismissal laws, that increase the adjustment costs of regular workers and discourages firms from adjusting their workforce in the presence of adverse economic conditions (Boeri and Jimeno 2005; Cahuc and Postel-Vinay 2002; Booth et al. 2002). According to these studies, a higher magnitude of firing costs of regular workers also increases the compliance costs of overall labour regulation and offers less flexibility to firms in balancing workforce in response to the product market competition. As a result, when faced with strict EPL, firms are likely to avoid the burden of adjustment costs and overall compliance costs labour regulations through employing temporary contract workers.

This large body of literature has two main features. First, it mostly focuses on the developed countries where labour regulations are perfectly enforced (Botero et al. 2004; Schneider and Enste 2000). Second, most of these studies have overlooked the role of the imperfect nature of enforcement in analyzing the effects of EPL

\footnotetext{
1 The share of temporary and short term contractual workers is increasing in many OECD countries over the past few decades. According to OECD Employment Outlook report (2010), it has increased four times in the Scandinavian countries and has almost doubled in other European countries. This segment, however, employed $6.8 \%$ point of the European Union working population in 2006. In the United States and the Japanese labour markets the same segment covers 6.2 and $4.9 \%$ point of the total workforce respectively (Heinrich et al. 2008).
} 
(Almeida and Poole 2013; Deakin et al. 2007). Much of the empirical literature has been extended to analyse both-the impact of strict EPL on the firm's demand for temporary contract workers, where perfect compliance with labour regulation was implicitly assumed, (Pierre and Scarpetta 2013; Cuesta and Martin 2009; Autor 2003), and the impact of enforcement intensity on compliance with labour regulation that constrains the demand for temporary contract workers (Almeida and Carneiro 2012; Ronconi 2010; Di Tella and MacCulloch 2005). However, none of these studies have looked at a case of labour markets in developing countries where there is a weak compliance with labour laws, and the de facto level of regulation is lower than the de jure level (Feldmann 2009; Djankov and Ramalho 2009).

Given this context, this paper aims to estimate the joint effects of EPL and variable enforcement intensity on the growth in a size of temporary contract workers in the organised (formal) Indian labour market. In particular, it examines-whether firms located in a stricter EPL regime hire differentially more temporary contract workers in response to variable enforcement intensity. India provides an ideal setting to study the growth in a size of temporary contract workers in the organised Indian labour market. India has highly restrictive employment protection laws but its enforcement is very poor. In India, the share of temporary contract workers has increased from $10 \%$ points to $27 \%$ point; the share of regular workers has decreased from $68 \%$ point to $54 \%$ point for the period 1995-2010 respectively (Fig. 1). The Industrial Dispute Act of 1947 (hereafter IDA, 1947) sets out the regulations governing employer-worker relations and covers various aspects such as the resolution of labour disputes, hiring and firing workers, closure of establishments, retrenchment, strikes and lockouts. This act covers regular workers who are directly employed in the formal sector, through long-term contracts, and are largely represented by the trade unions. However, temporary contract workers are exempted from the application of severance payment, mandatory notice or retrenchment authorisation from the state (Rajeev 2010; Deshpande et al. 2004). Such exceptions

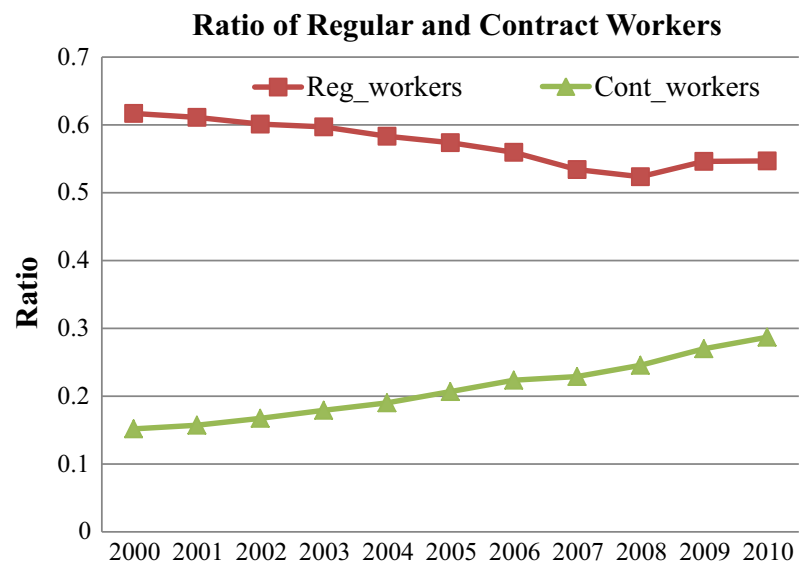

Fig. 1 Ratio of regular and temporary contract workers. Source: Annual Survey of Industries, various years 
from the legal compliance incentivise employers to hire an increasing number of contract workers due the flexibility it offers in the formal labour market (see Fig. 2).

The theoretical premise for an empirical analysis is derived from a simple model of dynamic labour demand developed by Adhvaryu et al. (2013) and Bertola (1990). According to their theoretical model, firing and compliance costs, as mandated by the strict EPL, factor into forward-looking employment decisions of the firm. If strict EPL, that protects the rights of regular workers and enforcement of those legal rights, are perfectly complied then it is possible for firms to circumvent those laws. They would do so by reducing the demand for regular workers and increasing the demand for temporary contract workers since the latter category of workers are exempted from legal compliance. In this context, we expect that firms located in strict EPL states, and faced with high enforcement intensity, are likely to experience higher incidence of temporary contract workers as compared to those firms located in less strict EPL states, facing low enforcement intensity.

For an empirical analysis, this paper uses the dataset of Annual Survey of Industries to compute the share of temporary contract workers. Next, it exploits variation in EPL and enforcement intensity measures, across thirty-one Indian states, for the period 2000-2007. The results suggest that the average effect of strict EPL and high enforcement intensity on the growth in size of temporary contract workers is positive and statistically significant across Indian states. The average effect is stronger for enforcement intensity than EPL. This implies that strongly enforced legal rights for regular workers increases the demand for temporary contract workers relative to strict EPL. Second, compared to firms in more flexible labour regimes, those in an increasingly restrictive labour regime hire differentially a higher number of temporary contract workers as response to variable enforcement intensities. And finally, the study report that the demand for temporary contract workers is rising in almost all labour intensive industries but the magnitude of the growth is slightly higher in inflexible states as compared to flexible states.

The topic discussed here is important for two reasons: first, it adds to the growing literature on labour laws and economics and provides empirical evidence on how

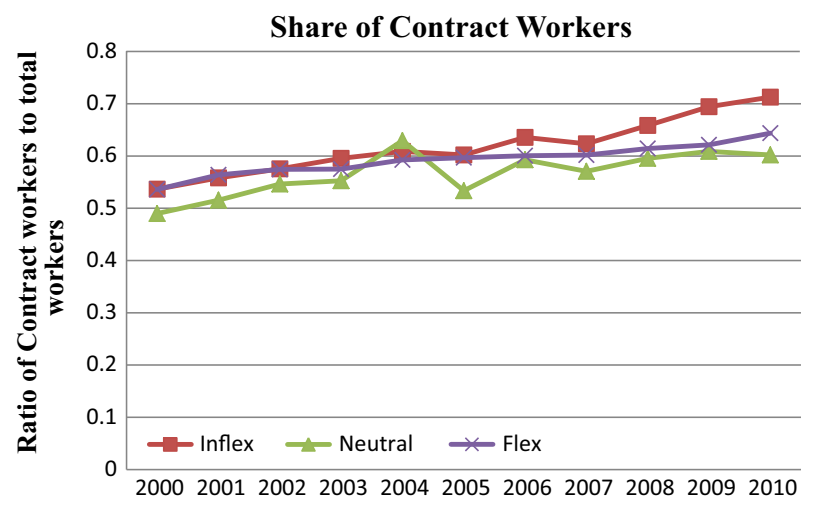

Fig. 2 Share of temporary contract workers across different labour regimes. Source: Annual Survey of Industries, various years 
labour regulation as stipulated in the national legislation and their variable enforcements generate incentives to use temporary contract workers. Second, in the context of India, labour regulation is criticised for being restrictive since its strict enforcement may create obstacles to economic activity. Due to variation in EPL and enforcement intensity across Indian states, some firms may be more affected than others; thus, the present study provides a better understanding of this complex interplay of institutions which is crucial for allocative efficiency in the labour market.

The paper is organised as follows: Sect. 2 provides a snapshot of previous studies; Sect. 3 provides an overview of labour regulation and enforcement climate; Sect. 4 describes the dataset and variables; Sect. 5 looks at identification strategy and summary statistics; Sect. 6 reports empirical results and robustness checks. Finally, Sect. 7 provides the conclusion.

\section{Previous studies}

The evolution and persistence of temporary contract workers and its effects on the formal labour markets has already been a subject of immense policy debate in countries with different regulatory frameworks and labour market conditions. In the introduction section, we provide an overview of few studies that have used different labour regulatory framework to study the factors responsible for the rise in the share of temporary contract workers. This regulatory framework was implicitly assumed that the labour regulation is perfectly complied. However, it is true in the context of developed countries but may not be true for the developing country like India. In this section, we provide an overview some landmark studies that have analysed the impact of different regulatory frameworks and labour market conditions on the rise of share of temporary contract workers. The US (United State of America) labour market is widely recognised as one of the most flexible labour market in the World. According to Autor (2003), the rise in a number of temporary contract workers in the US is causally related to the adoption of one class of exception by the US courts (i.e. an exception clause to legal doctrine of employment-at-will) — the implied contract right to ongoing employment by forty-six member states. On contrary, Kalleberg (2011) considers macro factors such as declining labour market regulation and oversight; diminished union power and global capital are in part responsible for the growth of temporary workers in the US economy. In the British labour market, the same growth is attributed to the European Commission (EC) directive that is being promulgated to prevent discrimination against temporary workers and extension of employment protection to protect legal rights of temporary contract workers (Forde and Slater 2005). In the context of Germany, Antoni and Jahn (2009) examines the impact of the amendment reforming the Labour Placement Act of Germany, in the period of liberalisation, has significantly increased the average employment duration of temporary workers. In response to persistence high unemployment faced since the early 1980s, many European countries have adopted widely varying labour policies concerning employment protection. Among them, the national policy instrument were leveraged in the 
direction of introducing the possibility of hiring temporary workers on flexible, fixed-duration contracts, aimed at encouraging job creation (see Cahuc and PostelVinay 2002; Booth et al. 2002).

In the Indian case, to begin with, the most influential study by Besley and Burgess (2004) examines the economic effects of two Central government level amendments (1976 and 1984 amendments) to the chapter VB of IDA, 1947 on the employment outcome. The labour regulation index constructed by Besley and Burgess (2004) (henceforth the BB index) has further been used by Aghion et al. (2008) to assess the effect of the entry regulation (The Licence Raj); by Hasan et al. (2007) to analyse the effect of trade reforms on labour demand elasticity; by Adhvaryu et al. (2013) to examine the sensitivity of industrial employment to local demand shocks; and finally by Sanyal and Menon (2005) to analyse the impact of labour regulation on firms' decision on the plant location and investment.

Dougherty (2009) using the Organization for Economic Co-operation and Development (OECD) index on the labour regulation argues that states with flexible labour laws, and plants in labour-intensive industries, experienced a fourteen percent improvement in total factor productivity compared to their counterparts. Using the same index, Golder and Aggarwal (2012) examined the determinants of informalisation of organised workforce by focusing on import competition and labour market rigidities. They report that in the post-liberalisation, import competition was responsible for creating an increasing number of casual jobs, temporary contract jobs compared to regular jobs, for workers with above primarylevel education. Ahsan and Pagés (2009) departs from the earlier analyses of labour regulation indices, which captures specific provisions on hiring and firing restrictions. In the paper they assess the effects of two cost components that could lead to labour market rigidities: first, the hiring and firing costs incurred by the employer while responding to global competition; second, the cost of resolving labour disputes that otherwise could have an effect on the firm size. The study suggests that states with inflexible labour laws and costly dispute resolution mechanisms experienced lower levels of output and employment growth, than states with flexible labour laws and less costly dispute resolution mechanisms. Fagernäs (2010) provides a new direction to the present debate. Her paper analyses the effect of labour dispute legislation, and dispute settlement process (as a proxy index for the enforcement mechanism), on the formal-informal employment divide in India. The study concludes that the relationship between judicial efficiency (as captured by constructing an indicator of Court efficiency), and formal employment is weak. Recently, Soundararajan (2013) examines the impact of minimum wage legislation and enforcement intensities in the Central government sphere (a similar measure we have used in this study) on wages and employment among low wage construction workers in India.

Our extensive survey of literature, on the Indian labour market, confirms that the labour regulation climate indeed has a significant negative impact on the economic growth and the employment level. One aspect which has been overlooked in these studies (except two -Fagernäs (2010) and Soundararajan (2013)), but has relevant policy implications, is the variations in labour regulation and enforcement intensity 
and their joint effects on the growth in a size of temporary contract workers in the Indian manufacturing sector.

\section{Labour regulation and enforcement climate}

\subsection{Labour regulation}

Under Article 246 of the Constitution of India, labour is a subject in the Concurrent List. India is a federal democracy wherein the Central (union) and State governments are competent to enact legislations. Due to joint jurisdictions, a large number of labour laws have been enacted to cater to different aspects of labour regulation. The central and state governments have powers to formulate rules to facilitate implementation of these laws. The industrial relation system is mainly governed by the Trade Union Act, $1926,{ }^{2}$ the Industrial Dispute Act, 1947, the Industrial Employment (Standing Order) Act, $1946^{3}$ and finally, the Contract Labour Act, 1970. ${ }^{4}$ These laws are mostly applicable to firms in the formal sector, and the execution of labour laws varies greatly across Indian states.

Among several legislations, the IDA deserves special attention in this paper. The main objective of the Act is to govern industrial dispute resolution procedures, and provide employment protection in case of unjust retrenchment, layoffs and lockouts. The IDA applies to a variety of establishments and industries in India. The terms 'industrial establishment' or 'industries' are used in the widest possible sense. It brings together almost all economic activities within the ambit of the Act, and is most widely applied in Indian organised sector. It also establishes a three-tiered dispute resolution mechanism comprising conciliation, arbitration, and compulsory adjudication of labour disputes.

In the IDA, the regular workers' layoffs and retrenchments are covered under Sections V-A and V-B respectively. Section V-A lays down regulations for establishments with 50 or more workers. For example, a retrenched worker is

\footnotetext{
2 The Trade Union Act of 1926 deals with the formation, and registration of trade unions by employers for the purpose of collective bargaining. Under this Act, trade union organizations are legally sanctioned and collective bargaining (at least nominally), strikes, and lockouts are regulated.

${ }^{3}$ The Industrial Employment (Standing Order) Act, 1946 provides rules and regulations governing the general terms and conditions of employment between the employee and the employer. Under this Act, the employer and the employee must agree on a set of rules and regulations governing the contractual employer/employee relationship. This Act provides income and job security to workers and safeguards the interest of both parties in case of a breach of the employment contract.

${ }^{4}$ The Contract Labour Act, 1970 was brought into effect to regulate the employment of contract labourers in certain establishments, and to provide for its abolition in certain circumstances. A contract labourer is defined in the Act as "one who is hired in connection with the work of an establishment by a principal employer (the firm) or through a contractor". The Act makes certain provisions for the welfare of contract workers as a whole including payment of minimum wages, certain health and sanitation facilities on the work premises, provident fund benefits and so on. However, it has been observed in many field studies that this Act is completely overlooked by principal firms and contractors, and the legal rights of contract workers are poorly enforced. Due to the lack of collective bargaining and legal protection from labour laws, contract workers continue to face vulnerable work conditions and poor welfare (Shyam Sunder 2011).
} 
entitled to compensation equal to 15 days' average pay for each year of service and for layoffs; every worker is paid fifty percent of basic wages and a dearness allowance for each day that they are laid off (maximum of 45 days). Regulations in Section V-B cover all establishments with 100 or more workers. This section is more stringent and requires firms to take government permission to layoff or retrench a single worker. Closing down of establishments requires 60 days (Section V-A) or ninety days (Section V-B) of prior notification to the government. Thus, both these sections of the IDA increase the costs of firing and compliance with the labour regulations. According to the IDA, contract workers are exempted from the application of severance payment, mandatory notice, or retrenchment authorisation. This creates an incentive for the employer to hire temporary contract workers differentially relative to the regular workers. Firms are free to hire and fire contract workers as market conditions change, without being subjected to the provisions of the IDA. (Rajeev 2010; Deshpande et al. 2004) observed that in many Indian states, a large number of temporary contract workers are being employed in work of a perennial nature, and is mostly being done by regular workers. Moreover, they are being paid almost $45 \%$ point less wages than the regular workers (Bhandari and Heshmati 2008). Therefore, excessive reliance on temporary contract workers has become a prominent feature of the Indian organised sector.

\subsection{Enforcement mechanism}

India's employment protection legislation dovetails job, income security, and collective bargaining to regular workers in the organised sector. However, their effectiveness relies on how well these legislations are enforced. The present industrial relations system allows each state to amend and execute all labour regulations prescribed by the central government. There are forty-five central government labour regulations (on which states can make further amendments), and in addition, hundreds of state level laws (Debroy 1997). This leads to a profusion of

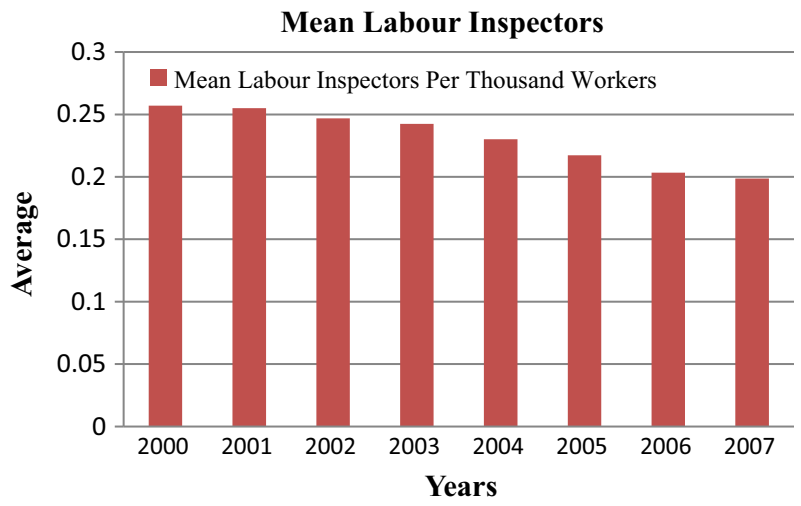

Fig. 3 Average number of labour inspectors (state sphere). Source: Pocket Book of Labour Statistics, various years 
labour legislations, especially across states, and makes enforcement increasingly burdensome. Enforcement of labour regulations is decentralised at the level of states. At the state level, the enforcement capacity is low due to poor human resource capability and lack of financial resources in the state labour departments. Industrial relation system is designed in a way that every Labour Inspector, Commissioner and Zone-officer, working under state jurisdiction, is responsible for enforcing multiple laws. Consequently, there is a gap between the number of labour inspectors available for inspection and their demand in enforcing these myriad acts.

Since the 1990s, there has been an overall decline in the total number of labour inspectors as well as factory inspections at the state level. In this paper, the enforcement intensity measured in terms of human capacity is the number of labour inspectors per one thousand workers. The mean number of labour inspectors is 0.23 for one thousand workers across states. In the year 2000, the average number of labour inspectors was 0.25. This further declined to 0.19 in 2007 (Figs. 3, 4). In the central sphere for minimum wage legislation, the mean number of labour inspectors declined from 6.51 in 2000 to 4.17 in 2010 for ten thousand workers in the scheduled industries (Soundararajan 2013). This decline is partially associated with a paucity of government spending on the labour department personnel (Shyam Sunder 2007), and partly due to the growing incidence of collusive agreements (e.g. a bribe) between employers and inspectors, the latter turning a blind eye to the noncompliance of laws (Basu et al. 2010; Rajeev 2010). Other institutional changes were adopted (adoption of 'New Industrial Policy') to curtail the power of the labour inspection system to attract foreign direct investments and promote a business friendly environment. This change, however, exempts certain types of firms from inspections (such as firms located in special economic zones (SEZ's), small and medium size industries, and firms registered under the shops and establishment acts) and is also allowed to self-certify compliance. As a result, heterogeneity in enforcement intensity at state levels is primarily driven by the state's economic policy, changes in institutional configurations, and their pursuit for foreign direct investments (Soundararajan 2013).

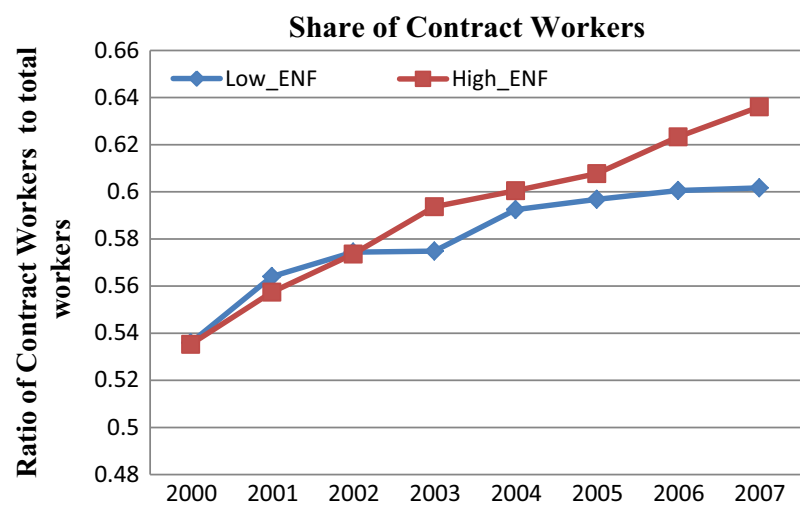

Fig. 4 Incidence of contract workers by enforcement intensities. Source: Author's own calculation 


\section{Data description}

This paper combines different data-sources: (1) Data on contract workers, value added and industry characteristics, (2) Data on labour regulation, (3) Data on Enforcement intensity, and (4) Data on state level indicators. The primary data source for this study is obtained from the Annual Survey of Industries (ASI) conducted by the Ministry of Statistics and Programme Implementation (MOSPI) of the Government of India. It is a state-industry level aggregate cross-sectional dataset on total output, value added, profit, employment (both regular and contract workers), capital stock, wages and so on, at the three-digit National Industrial Classification (NIC) industry level, and at the state level for the period 2000-2007. The ASI extends to the entire country. It covers all factories registered under Sections. 2m(i) and $2 \mathrm{~m}$ (ii) of the Factories Act, 1948, i.e. those factories that employ ten or more workers and use power; and those that employ twenty or more workers, without using power respectively. Our state-industry panel dataset contains data on twenty-five states and six union territories (UT's) for almost sixty-four three digit industries.

Data on the labour regulation index is drawn from the study by Besley and Burgess (2004). It is based on state-level amendments to the IDA for the period 1958-1992. This index captures the inter-state variation in labour regulation over time. The index on labour regulation takes values as follows: if there is no amendment, it scores ' 0 '; if the amendment is pro-worker, it takes the value of ' 1 '; and finally, if the amendment is pro-employer then the score is ' -1 '. A pro-worker (pro-employer) amendment was one that decreased (increased) a firm's flexibility in hiring and firing of workers while a neutral amendment left it unchanged. The BB index codes a direction of change if there are multiple amendments in a given year for each state. The cumulated sum of these scores in all previous years would determine the state's labour regime in a particular year. The BB index on the composite labour regulation ends in 1992. This paper reviewed the IDA, 1947 in a recent edition of Malik (2009) and collected almost nine state amendments that were enacted after 1992 - these are included in the appendix section of this paper. The BB index and its coding procedure was heavily criticised by (Bhattacharjea 2006). However, in later two studies, these criticisms have been used to correct the index (Ahsan and Pagés 2009; Gupta et al. 2009). Following Besley and Burgess (2004), and Gupta et al. (2009), this paper follows the method of cumulating the BB scores to categorise the states in three categories: pro-worker, pro-employer and neutral for each year. Based upon a revised measure, six states are classified as proemployer (flexible states) viz. Andhra Pradesh, Karnataka, Uttar Pradesh, Rajasthan, Gujarat and Tamil Nadu. Another fourteen states are classified as pro-worker states (inflexible states): Assam, Bihar, Jharkhand, Delhi (UT), Goa, Haryana, Himachal Pradesh, Madhya Pradesh, Chhattisgarh, Maharashtra, Orissa, Punjab, Kerala and West Bengal. The remaining eleven states are classified as neutral states: Chandigarh (UT), Dadara Nagar Haveli (UT), Jammu \& Kashmir, Manipur, Meghalaya, Nagaland, Pondicherry (UT), Tripura, Daman and Diu (UT), Uttaranchal, and Andaman and Nicobar (UT) (see Appendix of Table 8). 
In this paper, the enforcement intensity is measured in terms of human capacity: number of labour inspectors per one thousand workers. The data on the enforcement intensity corresponding to Annual Survey of Industry years are obtained from the appendix sections of Pocket book of Labour Statistics published by the Labour Bureau, Ministry of Labour and Employment of Government of India. To analyse the responsiveness of strict EPL, with variable enforcement intensity, we have categorised the enforcement intensity measure in two sub-indexes: high enforcement intensity, and low enforcement intensity at a state level (see Appendix-I). If the mean number of labour inspectors for a given state is higher than the overall mean value (0.23) of labour inspectors in our sample, then that state is referred to as having high enforcement intensity. For instance, the state of West Bengal has on an average 0.45 labour inspectors for one thousand workers making it a case of a state with a high enforcement intensity. In a similar vein, if mean number of labour inspectors is lower than overall sample mean of labour inspectors, then that particular state has been classified as low enforcement intensity. For instance, the state of Karnataka has on an average 0.19 labour inspectors, much less than the sample mean on enforcement intensity.

Finally, the data on control variables comes from the statistical abstracts of Indian states, various reports on Economic Survey, and the Annual Survey of Industries. We use the following control variables at the state level: per capita state domestic product, per capita road lengths, per capita electricity consumptions, and per capita state development expenditure.

\section{Identification strategy and summary statistics}

In this section, the study discuss the empirical methodology that examines whether firms located in stricter EPL states hire differentially more temporary contract workers in response to variable enforcement intensity. The identification strategy is closely related to Adhvaryu et al. (2013) who use state-industry and district level data to find that total employment in states/districts with more flexible labour regimes are more responsive to demand shocks. Exploiting variation in EPL and enforcement intensity, we first measure the impact of EPL and enforcement intensity on our dependent variable: the $\log$ ratio of contract workers to total workers at the state-industry level for the period 2000-2007.

At the aggregate level, the base regression specification is thus:

$$
\begin{aligned}
Y_{i, s, t}= & \alpha_{i}+\alpha_{s}+\alpha_{t}+\beta_{1}\left(E P L_{s, t}\right)+\beta_{2}\left(E N F O R C E_{s, t}\right)+\beta_{3}\left(E P L_{s, t} * E_{\text {NNFORCE }}\right) \\
& +\delta_{s, t}+\varepsilon_{\mathrm{s}, \mathrm{t}}
\end{aligned}
$$

$\left(Y_{i, s, t}\right)$ represents the log ratio of contract workers to total workers for industry (i), state(s) at time (t). The base regression Eq. (1) controls for macro shocks with industry fixed effects $\left(\alpha_{i}\right)$, state fixed effects $\left(\alpha_{s}\right)$ and for time-invariant state-industry variation with year fixed effects $\left(\alpha_{t}\right)$. Industry specific fixed effects take into account the macro shocks resulting from the product market competition. The state- 
specific fixed effects capture factors such as demography, culture and natural endowments. The year-specific fixed effects capture year-specific factors such as common shocks of industrial unrest, and amendments in the workfare programme etc. The coefficient of interests $\left(\beta_{1}\right)$ and $\left(\beta_{2}\right)$ estimate the average effect of EPL and enforcement intensity on state-industry level outcomes $\left(Y_{i, s, t}\right)$. As mentioned in the previous section, the measure on EPL is computed as a cumulative sum of statelevel amendments to the IDA. Enforcement intensity is measured in terms of total number of labour inspectors for one thousand workers for each state over years. In addition, the study also adds another coefficient of interest $\left(\beta_{3}\right)$ to the baseline specification that estimates the interactive effect of EPL and enforcement on the share of contract workers. $\left(\delta_{s, t}\right)$ is the time varying and state-specific vector of control variables. $\left(\varepsilon_{\mathrm{s}, \mathrm{t}}\right)$ represents the idiosyncratic error term. Our specification clusters standard errors at the level of state to deal with concerns of serial correlation (Bertrand et al. 2004).

At a disaggregate level, we estimate-how firms' demand for temporary contract workers varies across states with different labour regulation as well as with different levels of enforcement intensities by adding interaction dummies.

$$
\begin{aligned}
Y_{i, s, t}= & \alpha_{i}+\alpha_{s}+\alpha_{t}+\beta_{1}\left(E P L_{s, t}\right)+\beta_{2}\left(E N F O R C E_{s, t}\right)+\beta_{3}\left(I N F L E X-E P L_{s, t} * H I G H\right. \\
& \left.-E N F O R C E_{s, t}\right)+\beta_{4}\left(F L E X-E P L_{s, t} * L O W-E N F O R C E_{s, t}\right)+\delta_{s, t}+\varepsilon_{\mathrm{s}, t}
\end{aligned}
$$

In Eq. (2), the index on EPL is classified as either pro-worker $(+1)$, pro-employer $(-1)$ and neutral $(0)$, depending on the cumulative score of IDA for each state. Enforcement intensity is classified as high $(+1)$ and low $(-1)$ enforcement intensity, depending on the mean number of labour inspectors across states. Hence, $\left(\beta_{3}\right)$ and $\left(\beta_{4}\right)$ measure the differential effects of inflexible EPL (pro-workers regime) with high enforcement, and flexible EPL (pro-employers regime) with low enforcement on two dependent variables respectively. Sample states with neutral EPL (with '0' code) and average enforcement intensity (with ' 0.23 ' mean) are being treated as an omitted category. When faced with high firing costs, firms located in inflexible states would have strong incentives to hire more temporary workers than those firms already located in flexible states. Thus, we expect the magnitude of coefficient $\left(\beta_{3}\right)$ to be positive and larger than $\left(\beta_{4}\right)$ i.e. $\left(\left(\beta_{3}\right) \geq\left(\beta_{4}\right)\right)$.

Firms' decision to use capital intensive technology or labour intensive mode of production are also influenced by the labour regulation climate. Most of the industries in India are labour intensive hence, the negative of strict EPL is likely to affect the workforce composition of the firm. In this respect, the study test in specification (3) whether labour intensive firms recruit contract workers differently across states with flexible and inflexible labour regimes.

$$
\begin{aligned}
Y_{i, s, t}= & \alpha_{i}+\alpha_{s}+\alpha_{t}+\beta_{1}\left(E P L_{s, t}\right)+\beta_{2}\left(\text { ENFORCE }_{s, t}\right)+\beta_{3}\left({\text { INFLEX }-E P L_{s, t} * H I G H}\right. \\
& \left.- \text { ENFORCE }_{s, t} * \operatorname{LABINTENS}_{i, s, t}\right)+\beta_{4}\left(F L E X-E P L_{s, t} * L O W-\text { ENFORCE }_{s, t}\right. \\
& \left.* \text { LABINTENS }_{i, s, t}\right)+\delta_{s, t}+\varepsilon_{\mathrm{s}, t}
\end{aligned}
$$


To estimate the impact, the study adds additional variable-labour-intensity dummy that takes the value ' 1 ' if the industry belongs to the category labour-intensive industry and zero otherwise to $\left(\beta_{3}\right)$ and $\left(\beta_{4}\right)$ respectively.

\subsection{Summary statistics}

Before, we proceed to formal analysis, Table 1 present a descriptive statistics of all relevant variables used in this study. The average size of contract workers in a given industry-state pair is 1341 with the standard deviation of 7687 . The maximum value of contract workers (i.e. 2,74,266), with the value of the standard deviation, and their relative difference indicate that the growth of contract workers is heterogeneous across the industry-state pair. On the contrary, the relative difference between the maximum size of regular workers (i.e. 2,45,973) and a standard deviation (i.e. $12,815)$ indicates that the average number of regular workers is relatively less dispersed than those of contract workers. Notably, the difference between the maximum numbers of both types of workers is low. This explains that the variation in different EPL states causes firms to use either or both type of workers at a maximum level. There are on an average 105 factories in each industry-state pair. The mean cumulative score of EPL is $(0.31)$ across all states, which is more close to the value of EPL index (0.39), constructed by Deakins et al. (2007). The variation in

Table 1 Descriptive statistics

\begin{tabular}{lrrlcc}
\hline Variables & Obs & Mean & Std. Dev & Max. & Min. \\
\hline State-industry level outcomes & & & & & \\
Contract workers & 9586 & 1341.31 & 7687.44 & 274,266 & 0 \\
Regular workers & 9586 & 4105.05 & 12815.41 & 245,973 & 0 \\
Total workers & 9586 & 7048.15 & $19,571.75$ & 348,062 & 0 \\
Value added by contract workers & 9586 & 1250.02 & 2381.01 & 151421.4 & -578.5 \\
Total factory & 9586 & 105.82 & 246.29 & 4301 & 0 \\
Total output (in '000 INR) & 9586 & $51,472.38$ & $195,363.72$ & $4,493,838$ & $-79,257$ \\
State level institutions & & & & & \\
Employment protection legislation (EPL) & 9586 & 0.31 & 1.27 & 4 & -2 \\
Enforcement intensity (ENFORCE) & 9586 & 0.23 & 0.26 & 0.48 & 0.05 \\
State-industry level control variables & & & & & \\
Value added (in '000 INR) & 9586 & $68,433.93$ & 256,603 & $8,959,593$ & $-12,197$ \\
Net State domestic product (per capita in & 9586 & 252.74 & 139.94 & 847 & 57.86 \\
$\quad$ INR) & & & & & \\
Development expenditure (per capita in INR) & 9586 & $14,824.82$ & $10,612.96$ & 47,695 & 224 \\
Electricity consumption (per capita in INR) & 9586 & 1283.00 & 1870.14 & $14,761.84$ & 75.06 \\
Road lengths (per capita) & 9586 & $112,334.9$ & $88,606.91$ & 336,982 & 223 \\
\hline
\end{tabular}

The database is a balanced panel of three digit state industries that is present in the data in all 8 years and include an average of sixty-four three digit industries in the thirty-one Indian states over the period 2000-2007 
enforcement intensity across states appears to be low due to an overall decline in the total number of labour inspectors. Other state level variables, such as per capita state domestic product, per capita road lengths, per capita electricity consumption, and per capita state development expenditure exhibit remarkable heterogeneity in state level resource endowments and development indicators.

\section{Empirical results}

\subsection{Effects on the incidence of contract workers by EPL strictness and enforcement intensity}

It is evident from the previous sections that firms' decision to hire contract workers is highly influenced by various institutional factors specific to the particular country.

Table 2 Effects of EPL and enforcement intensity on the share of contract workers (Aggregate)

\begin{tabular}{|c|c|c|c|c|}
\hline State-industry panel & $\begin{array}{l}\text { (1) Log contract } \\
\text { workers }\end{array}$ & $\begin{array}{l}\text { (2) Log contract } \\
\text { workers }\end{array}$ & $\begin{array}{l}\text { (3) Log contract } \\
\text { workers }\end{array}$ & $\begin{array}{l}\text { (4) Log contract } \\
\text { workers }\end{array}$ \\
\hline EPL & $\begin{array}{l}0.0199 * * \\
(0.0101)\end{array}$ & $\begin{array}{l}0.035 * * * \\
(0.010)\end{array}$ & $\begin{array}{l}0.083 * * * \\
(0.031)\end{array}$ & $\begin{array}{l}0.056 * * * \\
(0.017)\end{array}$ \\
\hline ENFORCE & $\begin{array}{l}0.354 * * * \\
(0.128)\end{array}$ & $\begin{array}{l}1.054 * * * \\
(0.155)\end{array}$ & $\begin{array}{l}0.100 * * \\
(0.046)\end{array}$ & $\begin{array}{l}1.087 * * * \\
(0.158)\end{array}$ \\
\hline EPL*ENFORCE & & & $\begin{array}{l}0.321 * * * \\
(0.092)\end{array}$ & $\begin{array}{l}0.312 * * * \\
(0.027)\end{array}$ \\
\hline \multicolumn{5}{|l|}{ Controls } \\
\hline Log NSDP & & $\begin{array}{l}-0.423 * * * \\
(0.040)\end{array}$ & & $\begin{array}{l}0.113 * * * \\
(0.017)\end{array}$ \\
\hline Log DEV EXP & & $\begin{array}{l}-0.228 * * * \\
(0.025)\end{array}$ & & $\begin{array}{l}-0.224 * * * \\
(0.025)\end{array}$ \\
\hline Log electricity & & $\begin{array}{l}0.317 * * * \\
(0.026)\end{array}$ & & $\begin{array}{l}0.312 * * * \\
(0.027)\end{array}$ \\
\hline Log road & & $\begin{array}{l}0.115 * * * \\
(0.017)\end{array}$ & & $\begin{array}{l}0.041 * * * \\
(0.040)\end{array}$ \\
\hline $\begin{array}{l}\text { Fixed effects } \\
(\text { industry }+ \text { year }+ \text { state })\end{array}$ & No & Yes & No & Yes \\
\hline Constants & $\begin{array}{l}2.555 * * * \\
(0.032)\end{array}$ & $\begin{array}{l}3.279 * * * \\
(0.085)\end{array}$ & $\begin{array}{l}2.524 * * * \\
(0.033)\end{array}$ & $\begin{array}{l}1.068 * * * \\
(0.243)\end{array}$ \\
\hline Adj $R^{2}$ & 0.15 & 0.21 & 0.15 & 0.20 \\
\hline No. of observations & 9586 & 9367 & 9586 & 9367 \\
\hline
\end{tabular}

The database is a balanced panel of three digit state industries that is present in the data in all eight years and include an average of sixty-four three digit industries in the thirty-one Indian states over the period 2000-2007. We report robust standard error in parentheses and they are clustered at the level of states

* Significant at $10 \%$; ** significant at $5 \%$; *** significant at $1 \%$ 
In the context of India, this paper identifies variations in EPL and enforcement intensity in Indian states over several years as a major source of heterogeneous growth in the proportion of contract workers in the manufacturing sector. We began by testing our premise: whether firms located in stricter EPL states hire differentially more temporary contract workers in response to variable enforcement intensity. Table 2 presents the estimated results for Eq. (1)—whether strict EPL and high enforcement intensity induce demand for contract workers at the aggregate level. Col. (1) of Table 2, shows that the overall impact of EPL and enforcement intensity are positive and significantly associated with the share of contract workers. The average estimated effect is larger for the coefficient on enforcement intensity than EPL.

Next, we control for differential industry-state-year specific effects. The inclusion of these effects allows us to control for unobserved, time-varying, industry-state shocks that are potentially correlated with our variables of interest (thus exploiting changes within states over time). In addition to fixed effects, we control for state specific covariates to analyse robustness of our baseline specification. Inclusion of these control variables allows us to identify the effects of labour regulation, and enforcement that vary along the some dimension. It further mitigates concerns that economic development and growth are endogenous to industrial development, while controlling for these potentially important determinants of industrial performance (Aghion et al. 2008). Col (2) reports that the magnitude of coefficients becomes larger for both independent variables after controlling for fixed effects and state level covariates. The results indicate that strongly enforced legal rights for regular workers actually increase the demand for contract workers than strict EPL. Both the estimated coefficients are positive and significant but the magnitude of enforcement intensity is higher than EPL. High enforcement intensity that actually increases the overall compliance costs with labour regulation is likely to increase the demand for contract workers. The point estimate suggests that one unit increase in enforcement intensity leads to $1.05 \%$ point basis increase in the proportion of contract workers within an industry. Results obtained from Col. (1) and (2) shows that firms located in strict EPL and high enforcement regime are likely to hire more contract workers. However, a firm perceives a higher level of enforcement intensity as a stronger factor that influences their choice for contract workers than strict EPL.

The effectiveness of flexible or inflexible labour laws depends on how well they are being enforced in a particular context. As mentioned in the introduction, labour markets in developed countries perfectly complied, but this is not true for the labour markets of developing countries. Although India appears to be strict in terms of EPL on paper, but in practice the legislations are poorly enforced (Nagaraj 2004).

Next, the study tests the joint impact of EPL and enforcement intensity on the share of contract workers. In col. (3) and (4), we re-estimate the baseline specification by adding an interactive term i.e. (EPL*ENFORCE), to analyse the average impact of strict EPL when it is perfectly enforced on the firms' demand for contract workers. Using controls and fixed effects, the estimated impact of interaction term is large, positive and significantly different than zero for contract workers. The point estimate indicates that a unit increase in strictness of both EPL 
and Enforcement are likely to wield a positive impact on contract workers in stateindustry pair by $0.31 \%$ point. This implies that both firing costs as well as compliance costs (i.e. through effective enforcement), as mandated through strict EPL, act as pivotal factors in the employment decision. Thus, when faced with strict legal regimes, firms would probably circumvent those laws by reducing the demand for regular workers and increase the demand for temporary contract workers since the latter category of workers are exempted from legal compliance.

Table 3 Effects on the share of contract workers by variable EPL and enforcement intensities (Disaggregated)

\begin{tabular}{|c|c|c|c|}
\hline State-industry panel & $\begin{array}{l}\text { (1) Log contract } \\
\text { workers }\end{array}$ & $\begin{array}{l}\text { (2) Log contract } \\
\text { workers }\end{array}$ & $\begin{array}{l}\text { (3) Log contract } \\
\text { workers }\end{array}$ \\
\hline EPL & $\begin{array}{l}0.101 * * \\
(0.046)\end{array}$ & $\begin{array}{l}0.025 * * \\
(0.013)\end{array}$ & $\begin{array}{l}0.044 * * * \\
(0.013)\end{array}$ \\
\hline ENFORCE & $\begin{array}{l}0.124 * * * \\
(0.008)\end{array}$ & $\begin{array}{l}1.014 * * * \\
(0.155)\end{array}$ & $\begin{array}{l}1.593 * * * \\
(0.167)\end{array}$ \\
\hline $\begin{array}{l}\text { HIGH_EPL*HIGH_ENFORCE } \\
\left(\beta_{3}\right)\end{array}$ & $\begin{array}{l}0.448 * * * \\
(0.041)\end{array}$ & $\begin{array}{l}0.501 * * * \\
(0.040)\end{array}$ & $\begin{array}{l}0.617 * * * \\
(0.081)\end{array}$ \\
\hline $\begin{array}{l}\text { LOW_EPL*LOW_ENFORCE } \\
\left(\beta_{4}\right)\end{array}$ & $\begin{array}{l}0.287 * * * \\
(0.049)\end{array}$ & $\begin{array}{l}0.381 * * * \\
(0.048)\end{array}$ & $\begin{array}{l}0.592 * * * \\
(0.060)\end{array}$ \\
\hline \multicolumn{4}{|l|}{ Controls } \\
\hline Log NSDP & & & $\begin{array}{l}-0.373 * * * \\
(0.040)\end{array}$ \\
\hline Log DEV EXP & & & $\begin{array}{l}-0.200 * * * \\
(0.025)\end{array}$ \\
\hline Log electricity & & & $\begin{array}{l}0.325 * * * \\
(0.027)\end{array}$ \\
\hline Log road & & & $\begin{array}{l}0.189 * * * \\
(0.019)\end{array}$ \\
\hline $\begin{array}{l}\text { Fixed effects } \\
\text { (industry }+ \text { year }+ \text { state) }\end{array}$ & No & Yes & Yes \\
\hline Ho: $\left(\beta_{3}\right)-\left(\beta_{4}\right)=0$ & & & $\begin{array}{l}0.283 * * * \\
(0.004)\end{array}$ \\
\hline Constants & $\begin{array}{l}2.728 * * * \\
(0.035)\end{array}$ & $\begin{array}{l}2.732 * * * \\
(0.038)\end{array}$ & $\begin{array}{l}1.238 * * * \\
(0.251)\end{array}$ \\
\hline Adj $R^{2}$ & 0.16 & 0.20 & 0.22 \\
\hline No. of observations & 9586 & 9367 & 9586 \\
\hline
\end{tabular}

The database is a balanced panel of three digit state industries that is present in the data in all eight years and include an average of sixty-four three digit industries in the thirty-one Indian states over the period 2000-2007. We report robust standard errors in parentheses and they are clustered at the level of state

* Significant at $10 \%$; ** significant at $5 \%$; *** significant at $1 \%$ 


\subsection{Effects on the incidence of contract workers by variable EPL strictness and enforcement intensity}

In this section, we discuss the results on the differential response of firms towards contract workers that varies across states with different labour regulation as well as with diverse level of enforcement intensities as formulated in the Eq. (2). We expect that due to a restrictive legal environment, firms located in inflexible states would have strong incentive to hire more temporary workers than those firms who are already located in a flexible environment. Thus, the estimated effects would be larger in inflexible states as compared to flexible states. Col. (1) and (2) Table 3 reports that the differential response to contract workers is higher in strict EPL regime with high enforcement intensity; the response is quite low in states with low EPL and low enforcement intensity. In the same column, the coefficients on EPL and enforcement intensity reports the analogous results as presented in the previous section. In col. (3), we controlled for fixed effects and included additional control variables to check the robustness of results obtained from col. (1) and (2). The reestimated results are fully consistent with those obtained above. States that have strict EPL with high enforcement intensity are likely to witness an increasing number of contract workers than those states that have had a flexible labour regulation regime. The results obtained from the Table 2 also provide a strong case for differential response of contract workers, through rejecting the hypothesis that the response to contract workers is equal across EPL and enforcement regimes. The point estimate suggests that highly inflexible states, with strict enforcement intensities, experience $0.23 \%$ point higher incidence of contract workers relative to flexible states with lenient enforcement. This result is indicated in the Fig. (4) that captures the macro level trend.

\subsection{Effects on the incidence of contract workers across labour intensive industries by variable EPL strictness and enforcement intensity}

In India, almost all industries rely on labour intensive technology. The selection of technology for the production activities is susceptible to the local regulatory environment. In the previous two sections, it was seen that the variation in strictness in EPL and enforcement intensities across states leads to differential responses to the demand for contract workers. In this section, we exploit the response of these variations in flexible, inflexible and neutral labour regimes and test whether they vary across the labour intensive industries. We estimate the regression Eq. (3), analogous to our previous Eqs. (1) and (2). In this specification, we interact with the dummy variable for labour intensive industries with our main independent variables. Col. (1)-(3) in Table 4 reports the average effect of the interaction term that allows us to examine the differential effects for labour intensive industries across states. Controlling for macro trends and fixed effects, the average effect on the incidence of contract workers, in labour intensive industries, by variable EPL, and enforcement intensities, in the inflexible states, is somewhat higher compared to the flexible states. The null hypothesis: the response to temporary contract workers in labour intensive industries is equal across different EPL and enforcement regimes. The 
point estimates indicate that firms located in pro-worker labour states with a high enforcement intensity demand $0.13 \%$ point basis more contract workers than firms located in pro-employer states with low enforcement intensity.

\subsection{Endogeneity concerns}

Throughout this paper, we have considered the effect of EPL and enforcement intensity on the share of contract workers, but it cannot be denied that these effects could be driven by a reverse causality. A change in labour regulations does not

Table 4 Effects on the share of contract workers across labour intensive industries by variable EPL and enforcement intensities (Disaggregated)

\begin{tabular}{|c|c|c|c|}
\hline State-industry panel & $\begin{array}{l}\text { (1) Log contract } \\
\text { workers }\end{array}$ & $\begin{array}{l}\text { (2) Log contract } \\
\text { workers }\end{array}$ & $\begin{array}{l}\text { (3) Log contract } \\
\text { workers }\end{array}$ \\
\hline EPL & $\begin{array}{l}0.019^{*} \\
(0.011)\end{array}$ & $\begin{array}{l}0.034 * * * \\
(0.010)\end{array}$ & $\begin{array}{l}0.034 * * * \\
(0.010)\end{array}$ \\
\hline ENFORCE & $\begin{array}{l}0.508^{* * *} \\
(0.141)\end{array}$ & $\begin{array}{l}0.445 * * * \\
(0.134)\end{array}$ & $\begin{array}{l}0.985 * * * \\
(0.157)\end{array}$ \\
\hline $\begin{array}{l}\text { HIGH_EPL*HIGH_ENFORCE*LABINTENS } \\
\left(\beta_{3}\right)\end{array}$ & $\begin{array}{l}0.025 * * \\
(0.012)\end{array}$ & $\begin{array}{l}0.033^{* *} \\
(0.0124)\end{array}$ & $\begin{array}{l}0.041^{* * *} \\
(0.015)\end{array}$ \\
\hline $\begin{array}{l}\text { LOW_EPL*LOW_ENFORCE*LABINTENS } \\
\left(\beta_{4}\right)\end{array}$ & $\begin{array}{l}0.032 * * \\
(0.015)\end{array}$ & $\begin{array}{l}0.033^{* *} \\
(0.015)\end{array}$ & $\begin{array}{l}0.042 * * * \\
(0.0125)\end{array}$ \\
\hline \multicolumn{4}{|l|}{ Controls } \\
\hline Log NSDP & & & $\begin{array}{l}-0.437^{* * *} \\
(0.040)\end{array}$ \\
\hline Log DEV EXP & & & $\begin{array}{l}-0.238 * * * \\
(0.0255)\end{array}$ \\
\hline Log electricity & & & $\begin{array}{l}0.338 * * * \\
(0.0275)\end{array}$ \\
\hline Log road & & & $\begin{array}{l}0.125 * * * \\
(0.0177)\end{array}$ \\
\hline $\begin{array}{l}\text { Fixed effects } \\
\text { (industry }+ \text { year }+ \text { state) }\end{array}$ & No & Yes & Yes \\
\hline Ho: $\left(\beta_{3}\right)-\left(\beta_{4}\right)=0$ & & & $\begin{array}{l}0.1363 * * * \\
(0.0178)\end{array}$ \\
\hline Constants & $\begin{array}{l}2.545^{* * * *} \\
(0.032)\end{array}$ & $\begin{array}{l}2.568 * * * \\
(0.035)\end{array}$ & $\begin{array}{l}2.443 * * * \\
(0.0165)\end{array}$ \\
\hline $\operatorname{Adj} R^{2}$ & 0.16 & 0.19 & 0.21 \\
\hline No. of observations & 9586 & 9586 & 9586 \\
\hline
\end{tabular}

The database is a balanced panel of three digit state industries that is present in the data in all eight years and include an average of sixty-four three digit industries in the thirty-one Indian states over the period 2000-2007. We report robust standard errors in parentheses and they are clustered at the level of states

* Significant at $10 \%$; ** significant at $5 \%$; *** significant at $1 \%$ 
occur randomly. In this case, it is also possible that changes in labour regulation may result from an inconsistency in economic and political outcomes that would influence the costs and benefits of passing individual amendments to the IDA. In such a case, our estimates of these effects would be too high. Using exogenous sources of variations in the IDA, and instrumenting labour regulation measures would help address this concern.

Besley and Burgess (2004) found that most changes in labour regulation took place after 1977, following the declaration of a state of Emergency. This caused a shock to the incumbent sovereign status in the subsequent elections. The Congress party lost political power in sixteen out of the thirty-one sample states. The newly formed non-Congress governments in these states introduced new ideas for the development of industrial relations. Thus, early changes in the IDA can be associated with this political shock. Besley and Burgess (2004) suggest two measures for capturing the initial conditions that trigger political development in each state and their influence on labour regulation for the period post 1977 when

Table 5 Endogeneity concerns

\begin{tabular}{|c|c|c|c|c|c|c|c|}
\hline & $\begin{array}{l}\text { OLS } \\
1\end{array}$ & ${ }_{2}$ OLS & $\begin{array}{l}\text { Log } \\
\text { contract } \\
\text { workers } \\
\text { IV } \\
3\end{array}$ & $\begin{array}{l}\text { Log } \\
\text { contract } \\
\text { workers } \\
\text { IV } \\
4\end{array}$ & $\begin{array}{l}\text { Log } \\
\text { contract } \\
\text { workers } \\
\text { IV } \\
5\end{array}$ & $\begin{array}{l}\text { Enforcement } \\
\text { intensity } \\
\text { OLS } \\
6\end{array}$ & $\begin{array}{l}\text { Log } \\
\text { contract } \\
\text { workers } \\
\text { IV } \\
7\end{array}$ \\
\hline $\begin{array}{l}\text { Mean pre- } \\
1977 \\
\text { unionisation }\end{array}$ & $\begin{array}{l}0.149 * * * \\
(0.572)\end{array}$ & $\begin{array}{l}0.166^{* * *} \\
(0.535)\end{array}$ & & & & $\begin{array}{l}0.002 * * * \\
(0.000)\end{array}$ & \\
\hline $\begin{array}{l}\text { Mean non- } \\
\text { landlord } \\
\text { tenure }\end{array}$ & $\begin{array}{l}-1.901 * * \\
(0.957)\end{array}$ & $\begin{array}{l}-2.030 * * \\
(0.975)\end{array}$ & & & & $\begin{array}{l}0.0102 * * * \\
(0.0021)\end{array}$ & \\
\hline $\begin{array}{l}\text { Instrumenting } \\
\text { labour } \\
\text { regulation }\end{array}$ & & & $\begin{array}{l}0.044 * * * \\
(0.004)\end{array}$ & $\begin{array}{l}0.157 * * * \\
(0.417)\end{array}$ & $\begin{array}{l}0.103 * * * \\
(0.0255)\end{array}$ & & \\
\hline $\begin{array}{l}\text { Instrumenting } \\
\text { enforcement }\end{array}$ & & & & & & & $\begin{array}{l}0.050 * * \\
(0.021)\end{array}$ \\
\hline State effects & No & Yes & No & Yes & Yes & No & Yes \\
\hline Year effects & No & Yes & No & Yes & Yes & No & Yes \\
\hline Controls & No & No & No & No & Yes & No & Yes \\
\hline $\begin{array}{l}F \text { test } \\
\quad \text { instruments }\end{array}$ & 5.15 & 6.59 & & & & 7.56 & \\
\hline Prob $>$ F & 0.0198 & 0.0089 & & & & 0.005 & \\
\hline Adj $R^{2}$ & 0.47 & 0.49 & 0.12 & 0.12 & 0.11 & 0.05 & 0.08 \\
\hline Observations & 248 & 9586 & 9367 & 9367 & 9367 & 248 & 9586 \\
\hline
\end{tabular}

The database is a balanced panel of three digit state industries that is present in the data in all 8 years and include an average of sixty-four three digit industries in the thirty-one Indian states over the period 2000-2007. We report robust standard errors in parentheses and they are clustered at the level of states

* Significant at $10 \%$; ** significant at $5 \%$; *** significant at $1 \%$ 
political competition intensified: (1) the pre-1977 unionisation, and (2) the historical pattern of land tenure captured by the proportion of district in each state, which had non-landlord-based revenue collection systems. These two variables explain significant transitions in the industrial relations due to changes in political power from the Congress party to non-Congress regional parties. Those states where regional parties have a majority witnessed a more protective attitude towards labour regulation and welfare, than the Congress-ruled states. We explore two variables as our instruments for regulation measures restricted to amendments that took place after 1977. Col. (1) of Table 5 indicates the ordinary least square estimate of labour regulation measures from two instrumental variables for a sample of thirty-one states. Both instruments are strongly correlated with labour regulation ( $F$ statistics $=5.15$ ). The union variable is positively correlated with labour regulation, while the variable based on the proportion of districts with non-landlord based revenue collection systems is negatively correlated with labour regulation. In cols. (3) to (5) we report instrumental variable estimates of the effects of instrumented labour regulation on the proportion of contract workers. The results are robust to our instrument variables. ${ }^{5}$ It also implies that the effects of instrumenting labour regulation, on the growth of contract workers in Indian industries, indeed has a slightly larger impact than those reported by the OLS. The standard errors for the IV estimates are also larger than the OLS standard errors.

During the Emergency, a major transition in political control of states was accompanied by the revival of judicial activism in India. Raparelia (2013) observes that the Supreme Court of India, in the late 1970s, emerged as a resuscitate judicial authority, and protected the Court's independence following its capitulation during the Indira Gandhi imposed Emergency (1975-1977). The study argues that the emergence of judicial activism in India was largely influenced by the swelling of diverse social movements that emerged in the mid-1970s. During the period, Indian courts began to deliver various socio-economic entitlements in the Constitution, justiciable through its substantive re-interpretations, and implicitly strengthening enforcement mechanisms (Chatterjee 1998). Higher judicial activism had a spill-over effect on labour jurisprudence and industrial relations (Raparelia 2013). The study assumes that changes in the political climate during Emergency would have influenced the enforcement of pro-worker labour regulation (inflexible). Two instruments were used to see whether variation in the enforcement intensities is primarily due to changes in the Court's stance, and not from the industrial development to enforcement of labour regulation. In col. (6), the OLS estimates of two instrumental variables on the enforcement index is positive and significant ( $F$ statistics $=7.56$ ). This implies that the wave of changes in political climate was also associated with changes in the enforcement of labour regulation. Our instrumental variable estimate of the effects of instrumented enforcement intensity on contract workers is positive and significant. This indicates that the changes in the attitude of enforcement authorities towards labour regulation would have been

\footnotetext{
5 The $F$-statistics in the first stage regression is 7.26 (this is a state-year regression with standard error cluster at the state level), indicating that the instruments have some power in explaining the direction of labour regulation.
} 
influenced by the changes brought by the Emergency. This attitude, which still persists, can be seen in the manner in which the enforcement authorities differentially enforce labour laws.

As a robustness checks, this study presents two estimates of alternative specification in order to check the sensitivity of our findings. First, we replace our measures on EPL and enforcement intensity with alternative indexes proposed by Goswami et al. (2002), and Montag (2013) ${ }^{6}$ and Fagernäs (2010). ${ }^{7}$ The reestimated result in Table 6 confirms that the effects of EPL and enforcement intensity are positive and significant on the growth of contract workers in the Indian manufacturing sector. Second, In Table 7, we present another robustness check using the generalised method of moments (GMM) technique (see Arnellano and Bond 1991). We specify valid instruments in each time period for the first difference equation. Col (1) in Table 7 controls for year and industry fixed effects by including dummy variables, controls for states fixed effects by first differencing the data, and then controls for the panel bias instrumenting the differenced lagged dependent variable with lagged level of dependent variables dated $t-2$ and earlier. The coefficient on EPL and ENFORCE is still positive and significant. Next in col. (2) we include the more general specification of lags of the dependent and independent variables. The estimated effect of both EPL and ENFORCE is still positive and comfortably significant.

\section{Conclusion}

This paper estimate the joint effect of EPL and enforcement intensity on the incidence of temporary contract workers, by exploiting variation across space and time in the extent of EPL and enforcement intensity, in the Indian context. In particular, we examine whether firms located in a stricter EPL regime hire differentially a greater number of temporary contract workers in response to variable enforcement intensity. Our results indicate that the average effect of strict EPL and enforcement intensity on the incidence of temporary contract workers is positive and statistically significant across Indian states. This result corroborates with the theoretical prediction and argues that the overall strict EPL that protects the rights of regular workers and ensures their strong enforcement causes firms to hire more temporary contract workers relative to regular workers. We report that firms in inflexible labour regimes and those in flexible labour regimes hire differentially more temporary contract workers in response to variable enforcement intensities. Finally, we find that labour intensive industries located in inflexible states, witness

\footnotetext{
${ }^{6}$ The index on labour regulation constructed by Goswami et al. (2002) is based on a survey of entrepreneurs and managers in 11,000 manufacturing companies in India. Montag (2013) uses both indices proposed by Besley and Burgess (2004) and Goswami et al. (2002) to construct a combined index of labour regulation. The index takes a value of 1 if both indices do not show any changes, and -1 if either index contradicts the other.

7 Based on state level amendments to the IDA, Fagernäs (2010) constructs a proxy index on "enforcement act" that would allow for individual workers or employers to apply directly to the Labour Court for adjudication, or an amendment that raises the punishment for non-implementation of the award.
} 
Table 6 Robustness check-I

\begin{tabular}{lll}
\hline & Log contract workers & Log contract workers \\
& 1 & 2 \\
\hline EPL & $0.047^{* *}$ & \\
Enforcement acts & $(0.023)$ & \\
& & $0.064^{* * *}$ \\
Controls & Yes & $(0.024)$ \\
Fixed effects & Yes & Yes \\
(industry + year + state) & & Yes \\
Constants & $2.467 * * *$ & \\
& $(0.014)$ & $2.587 * * *$ \\
Adj $\mathrm{R}^{2}$ & 0.12 & $(0.033)$ \\
Observations & 9586 & 0.16 \\
\hline
\end{tabular}

The database is a balanced panel of three digit state industries that is present in the data in all 8 years and include an average of sixty-four three digit industries in the thirty-one Indian states over the period 2000-2007. We report robust standard errors in parentheses and they are clustered at the level of states

* Significant at $10 \%$; * significant at $5 \%$; *** significant at $1 \%$

Table 7 Robustness check-II

\begin{tabular}{|c|c|c|}
\hline & $\begin{array}{l}\text { Log contract workers } \\
1\end{array}$ & $\begin{array}{l}\text { Log contract workers } \\
2\end{array}$ \\
\hline Log contract workers ${ }_{t-1}$ & $\begin{array}{l}0.041 * * * \\
(0.012)\end{array}$ & $\begin{array}{l}0.043 * * * \\
(0.012)\end{array}$ \\
\hline EPL & $\begin{array}{l}0.040 * * * \\
(0.010)\end{array}$ & \\
\hline $\mathrm{EPL}_{t-1}$ & & $\begin{array}{l}0.099 * * * \\
(0.008)\end{array}$ \\
\hline ENFORCE & $\begin{array}{l}0.303 * * \\
(0.142)\end{array}$ & \\
\hline $\mathrm{ENFORCE}_{t-1}$ & & $\begin{array}{l}0.023 * * * \\
(0.010)\end{array}$ \\
\hline $\begin{array}{l}\text { Fixed effects } \\
\text { (industry }+ \text { year }+ \text { state })\end{array}$ & Yes & Yes \\
\hline Adj $R^{2}$ & 0.18 & 0.20 \\
\hline Observations & 8161 & 8161 \\
\hline
\end{tabular}

The database is a balanced panel of three digit state industries that is present in the data in all 8 years and include an average of sixty-four three digit industries in the thirty-one Indian states over the period 2000-2007. We report robust standard errors in parentheses and they are clustered at the level of states

* Significant at $10 \%$; * significant at $5 \%$; *** significant at $1 \%$ 
higher incidence of contract workers than those located in flexible states. Therefore, we conjecture that firms hire differentially more temporary contract workers in response to variable enforcement intensity to circumvent firing and overall mandated compliance costs and it further gives them more flexibility in adjusting the workforce.

This paper adds to the growing perception that-the difference between labour regulation and its actual enforcement, in developing countries, has not generated enough incentives for compliance with labour regulation. And therefore, firms prefer to use a greater number of contract workers to reduce labour costs thus enabling them to adapt to fluctuations in the product market competition.

This paper does not claim that the strict EPL and enforcement intensities are the only factors responsible for the rise of contract workers in the Indian economy. There are other factors such as state specific business environment, nature of the capital market, and foreign direct investment that could be responsible for shaping the industrial climate in India. Due to the lack of data at the state level we were not able to include these factors but we hope that these issues can be addressed through future research.

Acknowledgment I would like to thank my thesis supervisor and mentor Prof. Hans-Bernd Schaefer for his consistent support and supervision. I gratefully acknowledge the extensive feedback provided by Prof. Stephan Voigt, Prof. Sripad Motiram and Dr. Anne-Sophie Vandenberghe on earlier version of this paper. I am grateful to Prof. Robert Cooter and Dr. Massimiliano Vatiero for helpful comments and discussions at the International Conference on Law and Economics at Bilkent University (Turkey). Special thanks to two anonymous reviewers for their insightful comments and suggestions. All potential errors in data interpretation or handling are the author's responsibility.

\section{Compliance with ethical standards}

Conflict of interest The author would like to declare that he has no conflict of interest.

Open Access This article is distributed under the terms of the Creative Commons Attribution 4.0 International License (http://creativecommons.org/licenses/by/4.0/), which permits unrestricted use, distribution, and reproduction in any medium, provided you give appropriate credit to the original author(s) and the source, provide a link to the Creative Commons license, and indicate if changes were made.

\section{Appendix 1}

An Overview of Index on Employment Protection Legislation and Enforcement Intensity across Indian states

\begin{tabular}{lcc}
\hline States & EPL & ENFORCE \\
\hline Andaman and Nicobar (UT) & 0 & 0.13 \\
Andhra Pradesh & -2 & 0.22 \\
Assam & 1 & 0.09 \\
Bihar & 1 & 0.20 \\
\hline
\end{tabular}




\begin{tabular}{|c|c|c|}
\hline States & EPL & ENFORCE \\
\hline Chandigarh (UT) & 1 & 0.16 \\
\hline Chattisgarh & 1 & 0.21 \\
\hline Dadara Nagar Haveli (UT) & 0 & 0.09 \\
\hline Daman and Diu (UT) & 0 & 0.11 \\
\hline Delhi (UT) & 1 & 0.21 \\
\hline Goa & 1 & 0.24 \\
\hline Gujarat & -1 & 0.29 \\
\hline Haryana & 1 & 0.42 \\
\hline Himachal Pradesh & 1 & 0.21 \\
\hline Jammu \&Kashmir & 0 & 0.13 \\
\hline Jharkhand & 1 & 0.28 \\
\hline Karnataka & -1 & 0.13 \\
\hline Kerala & 1 & 0.15 \\
\hline Madhya Pradesh & 1 & 0.24 \\
\hline Maharashtra & 2 & 0.32 \\
\hline Manipur & 0 & 0.08 \\
\hline Meghalaya & 0 & 0.06 \\
\hline Nagaland & 0 & 0.05 \\
\hline Orissa & 1 & 0.19 \\
\hline Pondicherry (UT) & 0 & 0.06 \\
\hline Punjab & 1 & 0.22 \\
\hline Rajasthan & -1 & 0.27 \\
\hline Tamil Nadu & -2 & 0.30 \\
\hline Tripura & 0 & 0.15 \\
\hline Uttar Pradesh & -1 & 0.37 \\
\hline Uttaranchal & 0 & 0.21 \\
\hline West Bengal & 4 & 0.44 \\
\hline
\end{tabular}

Source: Author's own calculation (see Sect. 4 for the data description)

\section{References}

Adhvaryu, A., Chari, A. V., \& Sharma, S. (2013). Firing costs and flexibility evidence from firms' employment responses to shocks in India. The Review of Economics and Statistics, 95(3), 725-740. doi:10.1162/REST_a_00305.

Aghion, P., Burgess, R., Redding, S., \& Zilibotti, F. (2008). The unequal effects of liberalization: Evidence from dismantling the license raj in India. American Economic Review, 98(4), 1397-1412.

Ahsan, A., \& Pagés, C. (2009). Are all labour regulations equal? Evidence from Indian manufacturing. Journal of Comparative Economics, 37(1), 62-75.

Almeida, R., \& Carneiro, P. (2012). Enforcement of labour regulation and informality. American Economic Journal: Applied Economics, 4(3), 64-89.

Almeida, R., \& Poole, J. (2013). Trade and labour reallocation with heterogeneous enforcement of labour regulations. Institute of Labour Study (IZA). Discussion paper 7358. 
Antoni, M., \& Jahn, E. (2009). Do changes in regulation affect employment duration in temporary help agencies? Industrial and Labour Relations Review, 62(2), 226-251.

Arellano, M., \& Bond, S. (1991). Some tests of specification for panel data: Monte-Carlo evidence and an application to employment equations. Review of Economic Studies, 41(3), 277-297.

Autor, D. (2003). Outsourcing at will: Unjust dismissal doctrine and the growth of temporary help employment. Journal of Labour Economics, 21(1), 1-47.

Basu, A. K., Chau, N. H., \& Kanbur, R. (2010). Turning a blind eye: Costly enforcement, credible commitment and minimum wage laws. The Economic Journal, 120(543), 244-269.

Bertola, G. (1990). Job security, employment and wages. European Economic Review, 34(3), 851-886.

Bertrand, M., Duflo, E., \& Mullainathan, S. (2004). How much should we trust differences-in-differences estimates. Quarterly Journal of Economics, 119(1), 249-275.

Besley, T., \& Burgess, R. (2004). Can labour regulation hinder economic performance? Evidence from India. Quarterly Journal of Economics, 199(1), 91-135. doi:10.1162/003355304772839533.

Bhandari, A., \& Heshmati, A. (2008). Wage inequality and job insecurity among permanent and contract workers in India: Evidence from organized manufacturing industries. ICFAI Journal of Applied Economics, 7(1), 80-105.

Bhattacharjea, A. (2006). Labour market regulation and industrial performance in India: A critical review of the empirical evidence. Indian Journal of Labour Economics, 39(2), 211-239.

Boeri, Tito, \& Jimeno, Juan F. (2005). The effects of employment protection: Learning from variable enforcement. European Economic Review, 49(8), 2057-2077. doi:10.1016/j.euroecorev.2004.09. 013.

Booth, A. L., Dolado, J. J., \& Frank, J. (2002). Symposium on temporary work: Introduction. The Economic Journal, 112(480), F181-F188. doi:10.1111/1468-0297.00044.

Botero, J. C., Djankov, S., La Porta, R., López-de-Silanes, F., \& Shleifer, A. (2004). The regulation of labor. Quarterly Journal of Economics, 119(4), 1339-1382. doi:10.1162/0033553042476215.

Cahuc, P., \& Postel-Vinay, F. (2002). Temporary jobs, employment protection and labor market performance. Labour Economics, 9(1), 63-69. doi:10.1016/S0927-5371(01)00051-3.

Chatterjee, P. (1998). A possible India: Essays in political criticism. New Delhi: Oxford University Press.

Cuesta, M. B., \& Martin, M. E. R. (2009). Part-time employment: A comparative analysis of Spain and the Netherlands. European Journal of Law and Economics., 28(3), 223-256. doi:10.1007/s10657009-9109-7.

Deakin, S., Lele, P., \& Siems, M. (2007). The evolution of labour law: Calibrating and comparing regulatory regimes. International Labour Review, 146(3-4), 133-162. doi:10.1111/j.1564-913X. 2007.00011.x.

Debroy, B. (1997). Labour market reform. New Delhi: Allied Publishers.

Deshpande, L., Sharma, A., Sarkar, S., \& Karan, A. (2004). Liberalisation and labour: Labour flexibility in Indian manufacturing. New Delhi: Institute for Human Development.

Di Tella, R., \& MacCulloch, R. (2005). The consequences of labor market flexibility: Panel evidence based on survey data. European Economic Review, 49(5), 1225-1259. doi:10.1016/j.euroecorev. 2003.11.002.

Djankov, S., \& Ramalho, R. (2009). Employment laws in developing countries. Journal of Comparative Economics, 37(1), 3-13. doi:10.1016/j.jce.2008.10.003.

Dougherty, S. (2009). Labour regulation and employment dynamics at the state level in India. OECD Economics Department, working papers, No. 624.

Fagernäs, S. (2010). Labour law, judicial efficiency, and informal employment in India. Journal of Empirical Legal Studies, 7(1), 282-321.

Feldmann, H. (2009). The quality of the legal system and labor market performance around the world. European Journal of Law and Economics, 28(2), 39-65. doi:10.1007/s10657-008-9092-4.

Forde, C., \& Slater, G. (2005). Agency working in Britain: Character, consequences, and regulation. British Journal of Industrial Relation, 43(2), 249-271.

Golder, B., \& Aggarwal, S. (2012). Informalisation and industrial labour in India: Effects of labour market rigidities and import competition. The Developing Economies, 50(2), 141-169. doi:10.1111/ j.1746-1049.2012.00162.x.

Goswami, O., Dollar, D., Arun, A. K., More, V., Mookherjee, A., Mengistae, T., et al. (2002). Competiveness of Indian manufacturing: Results from a firm level survey. Washington, DC: Confederation of Indian Industry New Delhi and World Bank Washington.

Gupta, P., Hasan, R., \& Kumar, U. (2009). Big reforms but small payoffs: Explaining the weak record of growth in Indian manufacturing. India Policy Forum, 5(2), 59-123. 
Hasan, R., Mitra, D., \& Ramaswami, K. V. (2007). Trade reforms, labour regulations and labour demand elasticities: Empirical evidence from India. Review of Economics and Statistics, 89(3), 466-479.

Heinrich, C. J., Peter, R., \& Troske, K. (2008). The role of temporary help employment in low-wage worker advancement. In D. Autor (Ed.), Studies of labour market inter mediation. Chicago: University of Chicago Press.

International Labour Organisation. (2012). World of work report: Better jobs for a better economy. Geneva: ILO.

Kalleberg, A. L. (2011). Good jobs, bad jobs: The rise of polarized and precarious employment systems in the United States-1970s to 2000s. New York: Russell Sage Foundation.

Malik, P. L. (2009). Industrial law: Manual of central labour and industrial laws incorporating state amendments with rules, regulations and select notifications. Lucknow: Eastern Book Company.

Montag, J. (2013). Is pro-labour law pro-women? Evidence from India. Mendel University, MENDELU working paper-40.

Nagaraj, R. (2004). Fall in the organised manufacturing employment: A brief note. Economic and Political Weekly, 24(9), 3387-3390.

OECD. (2010). Employment outlook. Paris: OECD.

OECD. (2014). Employment outlook. Paris: OECD.

Pierre, G., \& Scarpetta, S. (2013). Do firms make greater use of training and temporary employment when labour adjustment costs are high? IZA Journal of Labor Policy, 2(1), 15.

Rajeev, M. (2010). Contract labour act in India: A pragmatic view. International Journal of Economic Policy in Emerging Economies, 3(3), 237-252.

Ronconi, L. (2010). Enforcement and compliance with labor regulations in argentina. Industrial and Labor Relations Review, 64(4), 719-736.

Ruparelia, S. (2013). A progressive juristocracy? The unexpected social activism of India's supreme court. Kellogg Institute, working paper-391.

Sanyal, P., \& Menon, N. (2005). Labour disputes and the economics of firm geography: A study of domestic investment in India. Economic Development and Cultural Change, 53(4), 825-839.

Schneider, F., \& Enste, D. (2000). Shadow economies: Size, causes, and consequences. Journal of Economic Literature, 38(1), 77-114. doi:10.1257/jel.38.1.77.

Shyam Sundar, K. R. (2007). Contract workers: The need for 'community of interest' perspective. Indian Journal of Labour Economics, 50(4), 807-820.

Shyam Sunder, K. R. (2011). Non-regular workers in India: Social dialogue and organizational and bargaining strategies and practices. Geneva: Industrial and Employment Relations Department, International Labour Office.

Soundararajan, V. (2013). Minimum wages and enforcement in india: Inverted U-shape employment effects. Institute of Labour Study (IZA), 8th World Bank-IZA conference papers.

World Bank. (2012). World development report 2013: Jobs. Washington DC: World Bank. doi:10.1596/ 978-0-8213-9575-2. 